\title{
Organization Identifier Type Code
}

National Cancer Institute

\section{Source}

National Cancer Institute. Organization Identifier Type Code. NCI Thesaurus. Code C93873.

A coded value specifying the kind of organization identifier. 